\title{
Change model for a school-based program to promote oral hygiene practices among Indian school children
}

\author{
Rashmi Mehra* \\ Department of Public Health and Health Promotion, Brunel University London, Uxbridge, UK
}

Received: 14 May 2021

Revised: 14 June 2021

Accepted: 15 June 2021

*Correspondence:

Dr. Rashmi Mehra,

E-mail: drrashmimehra@gmail.com

Copyright: ( ) the author(s), publisher and licensee Medip Academy. This is an open-access article distributed under the terms of the Creative Commons Attribution Non-Commercial License, which permits unrestricted non-commercial use, distribution, and reproduction in any medium, provided the original work is properly cited.

\begin{abstract}
The present paper addresses basic evaluation and procedural concepts that are involved in the process of implementing a school-based program to promote oral hygiene practices among Indian school children using the I-change intervention mapping model. Core components for effective intervention design and implementation are presented as part of a comprehensive model composed of six stages along with in depth discussion about sustaining each step under the Ichange model providing with the imminent need for such a school based program in India. This model systematically addresses the design program, the production of said program called insta-brush. Special attention has been given to the planned program implementation delineating suggested sequence of implementation followed by comprehensive measurement of the impact of the program with proposed process and summative evaluation plans. Assessment tools and evaluation strategies are recommended and illustrated based on evaluations of interventions implemented in school based oral health programs worldwide.
\end{abstract}

Keywords: Oral health, Interventions, Implementation process, Assessments, Sustainability, Evaluation model

\section{INTRODUCTION}

Good oral health has been acknowledged as a precondition for good health. ${ }^{1}$ Oral health is now considered fundamental to overall individual health, well-being and quality of life (QOL). Good oral health enables people 'to eat, speak and socialise without pain, discomfort or embarrassment'. ${ }^{2}$ The impact of oral diseases is not restricted to the individual's pain and discomfort, but has a larger effect on their overall health and QOL. This in turn also affects the community at large, through health system needs and allied economic costs. ${ }^{3}$

The most prevalent oral health problem in the world is dental caries which is a chronic infectious disease affecting approximately $60-90 \%$ of school-children and adults across the world. ${ }^{4}$ India also presents a similar situation prevalence of dental caries in India ranging from $31 \%$ to $90 \% .{ }^{5,6}$ However, caries experience was found to vary with a number of sociodemographic factors including age, gender, socioeconomic status, ethnicity and also with other prevailing lifestyle conditions and comorbidities including diet, medical conditions of the patient, oral hygiene practices. ${ }^{7,8,9}$ It has also been found that not all areas of the oral cavity are equally susceptible to caries. ${ }^{6,7}$ Mittal et al (2014) found $80 \%$ prevalence of gingivitis among 12year-old school children in India. ${ }^{10}$ Despite the high prevalence of oral disease, a clear social gradient is consistently associated with greater decayed-missingfilled teeth (DMFT) scores (levels of caries experience) $(\mathrm{p}<0.0001) .{ }^{11}$

Several epidemiological studies have found that pain, discomfort and chewing difficulties caused by dental caries impact children's quality of life. ${ }^{12,13}$ Apart from the pain and discomfort, it also culminates into financial burden for the family and community at large. ${ }^{14}$ Dental caries during childhood could have an adverse impact on the life of those suffering and their parents due to the distress among 
affected children including absenteeism (pooled odds ratio, $1.43 ; 95 \%$ confidence interval, 1.24 to 1.63 ) from school. Poor oral health has also been associated with greater odds of poor academic performance (pooled odds ratio, 1.52; $95 \%$ confidence interval, 1.20 to 1.83 ) and 12 times more likelihood of having restricted activity days than those with good oral health. ${ }^{15,16}$ An estimated 50 million school hours are lost each year to oral health problems affecting school children's academic and potential success in their adult life. ${ }^{17}$

In such a situation, efficient oral hygiene has been found to have a caries preventive effect. The quality of the cleaning appears to be more important than the frequency of performing the cleaning including the use of a fluoride dentifrice. ${ }^{18}$ Oral hygiene (tooth brushing at least twice a day) is one of the most important methods for the control and prevention of dental caries and periodontal diseases. ${ }^{19}$ Oral hygiene practice (tooth brushing) varied to a large extent among school children in India (25\% to $61.9 \%$ cleaned their teeth two or more times a day). ${ }^{19,20}$

Therefore, oral hygiene practice promotion forms the forte for most oral health promotive programs across the globe. As mentioned, prevalence of dental decay is high among school children, therefore making oral health promotion for school children remains the need of the hour.

It has been found that school based oral health programs are one the most effective ways of introducing the importance of oral health and at the same time inculcate oral hygiene practices like tooth brushing and mouth rinsing. ${ }^{15,17}$ In their 2005 review of oral health promotion programs to improve oral hygiene and gum health, Watt and Marinho conclude that the majority of the welldesigned recent studies in schools had shown short-term positive effect on plaque levels. ${ }^{21}$ These programs included four one-hour oral health lessons for ten-year olds in a four-month period, three lessons over six months for adolescents and intensive school-based oral hygiene instruction. An effective platform for oral health promotion is provided by schools because of their wide reach surpassing over 1 billion children worldwide. Since school years are the most influential stages of children's lives, oral health messages introduced and reinforces at this stage help develop lifelong beliefs, attitudes and skills. ${ }^{17}$

In order to address the problem of dental caries among school children, intervention mapping approach was used to design, implement and evaluate an intervention program. The steps involved have been described below. ${ }^{22}$

\section{INTERVENTION MAPPING}

\section{Step 1: needs assessment}

\section{Set up a planning group/program stakeholder}

This group would be formed prior to the designing of the interventions (January 2020) and in order to optimise the interventions' implementation it would continue to function till the end of the intervention period (from May 2020 to May 2022).

The planning group would include health educators from the local health authority, program developers (experts from tertiary dental centres) and Delhi government school principals and teachers. The group would be led by a dental public health specialist and meet once a month over a 4month period to discuss, deliberate and strategize an oral health promotive program, assess the potential barriers and facilitators to tooth brushing among school children of different age groups, including findings from extensive literature review (Stein et al 2017). They would be engaged in intervention development (i.e. outcomes, delivery, practical strategies and feasibility), implementation planning and evaluation planning. Contact would also be made with organizations that could assist with intervention design and implementation including the Indian Dental Association and Delhi Dental Council for technical support.

\section{Conduct a needs assessment to create a logic model of the problem}

The intervention mapping process follows the assumption that health outcomes can be altered by targeting related health behaviours and their determinants. ${ }^{22}$ The present intervention program would deal with only behavioural factor of poor oral hygiene practices at play for the problem at hand.

Health problems which present greater threat to QOL would be prioritised. This would be followed by assessment of behaviours and environmental conditions related to the prioritised threats. This process is referred to as a "reductionist" approach. We would be using the expansionist approach in which the health problem at hand is the further analysed and reviewed to identify behavioural and environmental conditions at play. ${ }^{22}$ To do this, following was done:

\section{Literature review}

Literature review was conducted. Although oral health problems usually do not present to be life threatening, they still remain a major public health problem because of their high prevalence and widely recognized contribution to social, economic and psychological consequences. Oral health impacts an individual's quality of life which is an essential component of general health and well-being widely recognized by the WHO as an important segment of its global oral health program. ${ }^{23}$

Oral diseases cause problems including painful chewing, reduced food intake with resultant weight loss, loss of sleep, and low self-esteem. In case of school children, there is associated poor performance in school with a significant impact on the QOL of the individual associated with dental decay and its consequences. ${ }^{24}$ 
We sought out both the determinants of poor oral hygiene practices and theories that could explain poor oral hygiene practices in children. Furthermore, group interviews with school children and their parents were performed to get an insight.

Behavioural interventions to reduce caries have been based on a variety of behavior change theories and approaches including social cognitive theory, health beliefs model, theory of planned behavior, self-determination theory, self-efficacy theory and motivational interviewing (MI). ${ }^{25,26}$ The health beliefs model assesses the value that an individual places on the want to avoid illness associated with a certain health behaviour along with their belief that a change in health behaviour can prevent illness. ${ }^{27}$ Health beliefs model guided promotive methods have been advantageous in promoting oral hygiene practices such as brushing and flossing. Applying this theory to the prevention of dental caries in children suggests that both the carer/parent and child must believe that the child is susceptible to dental decay, acknowledge the importance of oral health and that caries can be prevented by ensuring good oral hygiene practices. ${ }^{28}$ Since a number of different theories have been implicated in the resultant oral hygiene habits and behaviour, the integrated change model was used for planning this intervention.

\section{Qualitative interviews}

Qualitative semi-structured interviews would be conducted with parents/carers of school children of different age groups, junior, middle and senior school. Children over 7 years would also be interviewed as they are usually not supervised or helped by parent/carer while tooth brushing. ${ }^{29}$

Participants would be purposively sampled to ensure inclusion of parents and children living in different districts of Delhi ranging in gender, children's age, ethnicity, native language, dental caries experience and dental attendance patterns. Potential participants would be identified from previous records of mobile dental clinics functioning at various Delhi government schools and community allopathic dispensaries. Interviews would be conducted at participants' homes, at mobile dental clinics, at a research institute and by telephone. The aim of these interviews is to explore the oral health behaviours of school children and to identify the theoretical barriers and facilitators to better oral hygiene practice.

\section{Context of intervention}

\section{Population}

All school children studying in Delhi government schools were included in the study.

\section{Setting}

The study was conducted in Delhi government schools.

\section{Community}

It include the nearest primary health center equipped with a dentist.

\section{Program goals}

In order to improve dental caries status of school children in Delhi government schools by increasing the appropriate use of tooth brushing and mouth rinsing among them.

\section{Step 2: specify program outcomes and objectives}

The program outcomes and objectives are derived from the logic model of change as depicted in Figure 2 and utilised to complete matrix of program outcomes and objectives. ${ }^{30}$ The specific objectives associated with target behaviour along with the stage of the I-change model have been listed in Table 1.

Using the integrated change model, behavioural and environmental outcomes are divided into performance objectives. Table 1 shows the developed matrix of change depicting behavioral outcomes, performance outcomes, and associated determinants.

\section{Step 3: design program}

The planning group with the help of public health professionals together design the intervention program. A list of appropriate change objectives was made for each of the target behaviours based on the I-change model in Table 1 , along with an apt practical application which would then be incorporated into the final intervention program (Table 2).

\section{Planning intervention}

\section{Program theme}

The central theme of the intervention program was introduction of an animated character- brushing, rinsing and oral hygiene promoter (BRO) (Figure 3 ) who would be shown as a cricketer owing to the wide popularity of the sport in India. He would be depicted in a series of animated videos educating school children about importance of oral health and hygiene.

\section{Program components}

The program broadly would include a 4-pronged strategy with 4 essential elements to it:

\section{Part 1: animated video}

A series of animated videos featuring the cricketer animated character BRO would be developed. This series would be names 'bestfriendswithBRO'. The videos for the children would be of three levels in order to cater to different age groups- junior, middle and senior school. 
Such a division is for administrative convenience as all government schools in India are divided into these 3 divisions. Therefore, contents of the video would be simplified and explained on the basis of these divisions.

Videos (Figure 4) for the children would include details of importance of oral health, methods of maintaining oral hygiene, importance of oral hygiene. Furthermore, each video would have 2 supplementary videos- one for parents and the other for the teachers in charge. The videos for teachers would serve as an operational guide providing them with more in depth and background information as well as a detailed demonstration of tooth brushing technique for each age group and frequently asked questions. The video for parents would be shown to parents on the three open days (result days) annually, at the end of each term.

Part 2: demonstration of tooth brushing by teachers of each class (as learnt from video adapted for teachers)

Each teacher would also be responsible for a monthly demonstration of tooth brushing with a short discussion on need for tooth brushing twice a day with fluoridated dentifrice and mouth rinsing after meals.

Part 3: Instagram page (@INSTABrush-INterventionS for teaching adolescents and children tooth brushing) with all videos for reinforcement

A dedicated Instagram page with complete library of animated videos shown in school to be available for reference and reinforcement. This page would also have copies of the flyers given to parents.

\section{Part 4: introduction of daily tooth brushing record in school diary}

Introduction of a separate column with two check boxes to record daily tooth brushing by the child. Instructions to be given by teacher to parents of junior school children to fill this for their children on a daily basis, while parents of middle and senior school students are urged to ensure that their children record daily tooth brushing.

\section{Scope}

The current intervention program would be limited to Delhi government school teachers and students as Delhi is the capital city of India with over 2500 government run schools including 'kendriya vidyalayas' (central schools) (directorate of education (DoE), GNCTD). This program would be limited to providing oral health related education for a limited times (three in an academic year) in the year. Since the schools have limited resources to ensure tooth brushing in school, parents are involved and provided guidance to ensure tooth brushing a mouth rinsing to be done at home. It has been found that to ensure successful tooth brushing program in a number of countries, involvement of home environment was imperative. ${ }^{31,32}$

\section{Program sequence}

The proposed intervention program would be designed in 3 months starting in May 2020 after deliberation and consensus of the planning group.

Every 4 months, starting in May, a tooth brushing demo by teacher with video would be played for all school children in their classroom. This would be followed by a 30 minutes long discussion by the class teacher as suggested by Watt and Marinho. ${ }^{21}$ On every open day at the end of each term (September, January and April), parents would also be shown an oral health educational video followed by a 30 minutes discussion with the class teacher discussing about the importance of oral health and need for oral hygiene. In addition, flyers would be distributed to take home with them.

The program would be designed to run for 2 years on the outset in line with previous Delhi government initiatives like the mobile dental health clinic under the national health mission. This period can later be extended further following process and outcome (summative) evaluation of the program.

At the beginning of this period, in May, 2020, a pilot baseline assessment would be made for 3 randomly selected schools. Process evaluation and outcome evaluation would be done at the end of every 6 months and 1 year.

\section{Step 4: produce program}

\section{Refine program structure and organization}

In order for the program to function smoothly, the planning group will setup an initial meeting with the Directorates education and health department of each of the 11 districts of Delhi. Following which the directorates will chair a meeting with the principals of all schools of their district, to short list staff and break-up of student population in schools. A consent form would be circulated among the students to ensure consent from the parents for this intervention. The consent form would clearly state the aims, objectives and methodology of the intervention program along with the potential benefits. Each directorate education and directorate health would form a combined district level task force called 'dant rakshak' (tooth saviours), comprising of nominated members from Health and Education department in order to ensure smooth functioning, material procurement and dispersal in the respective district. Each task force would have 10 participants.

\section{Prepare plans for program materials}

The planning group along with dental and public health experts would finalise on the content of the animation video including script and pictorial depiction of dental decay, etc. Content would be based on current evidence for 
the use of fluoride containing dentifrice for tooth brushing and oral hygiene. ${ }^{33}$ The videos would include standardized presentation of four key areas (general introduction to oral health, mechanisms of action of plaque and dental decay and oral hygiene methods including tooth brushing and mouth rinses after meals). The educational session would also be designed to positively influence attitudes (e.g., instilling knowledge, causes and consequences), subjective norms (e.g., current recommendations for healthy behaviors; active learning through group discussion), and perceived behavioral control. A guide to conduct the educational session would be included in the video adaptation for the teachers. The supplementary takehome flyers would contain generic oral health information to pass on to their parent/carer.

\section{Draft messages, materials, and protocols}

The scripts for the videos and content of the flyers would be conceptualised and written by 2 oral health and public health expert which would be reviewed by all the members of the planning group. A total of 9 videos would be made, tailored for each age group- junior, middle and senior school.

\section{Pretest, refine, and produce materials}

Session, flyer and video content once developed, would be reviewed by 5 other public health experts and the planning group for comprehensibility, informativeness and narrative coherence. ${ }^{34}$ It would then be approved by teachers who had provided consent for intervention delivery within their allocated teaching time.

\section{Step 5: plan program implementation}

To ensure smooth implementation, a brief plan for program implementation would be formulated in the following steps.

\section{Stakeholder identification}

Linkage approach would be used to identify potential stakeholders: research group: Department of Public Health Dentistry, Maulana Azad Institute of Dental Sciences, Government of NCT Delhi; resource group: Public Health Foundation of India; target group: principals and staff of all Delhi government schools; support group: National Institute of Health and Family Welfare, Delhi; and finance group: Department of Health and Family Welfare, Delhi Government

\section{Outcomes and performance objectives}

Outcome was that principals and staff of all government schools to adopt this program and work for it. Performance objectives included adoption: the 'dant rakshak' task force holds a meeting in each district and all Delhi government school principals decide to adopt the \#INSTABrush program pledging school time and facilities to improve oral health and hygiene of the school children by signing the program adoption form; implementation: All Delhi government school principals will implement the \#INSTABrush program in their respective schools; and sustainability: all Delhi government school principals would be urged to draft their own school Oral health policy in order to inculcate the \#INSTABrush program.

\section{Design program}

The performance objectives would be matched with determinants including improving self-efficacy and attitude of target group and then dealt with appropriate BCTs like verbal persuasion and argument.

These could be done by an educational discussion or video conferencing with the target group (principals and staff of all Delhi government schools) along with experts from the fields of public health and oral health. Elaboration of benefits of the program and advantages of implementation could also be circulated as written report.

\section{Step 6: evaluation}

The program would be evaluated at different stages by formative and summative evaluation. Figure 3 depicts the framework of the proposed program.

Evaluation plan for the proposed program would be in the following manner.

\section{Effectiveness and process questions}

Process evaluation would include the following.

Context: This would include assessing number of participating schools, consent from parents of wards, availability of brushing model and other equipment needed for playing videos and conducting an educational session. It would also include availability of printed flyers. It would also include the presence and functioning of the INSTABrush page on Instagram.

Reach: This would include number of sessions conducted, number of children attending each session, number of parents attending each session.

Satisfaction: Following every session with children and parents, the teachers must get a feedback form filled by all in attendance. This would be distributed during each of the sessions. An online feedback form would also be available on the Instagram page to provide satisfaction feedback for the page.

\section{Effectiveness questions}

They would include the following.

Survey to be conducted among students about adoption of tooth brushing and mouth rinsing after meals after 6 weeks 
of each session. ${ }^{35}$ This would include awareness, motivation and action assessing questions.

Oral hygiene status assessed at baseline and then on completion of one year by oral hygiene index by Greene and Vermillion, 1964. This is conducted among appropriate sample size in 3 randomly chosen schools. ${ }^{36}$

WHO oral health survey conducted at baseline and then on completion of each year among appropriate sample size in 3 randomly chosen schools of Delhi in order to assess dental caries and periodontal status. ${ }^{37}$

\section{Planning designs for conducting evaluations}

Process evaluation: A monthly district level report to be reviewed by the 'dental rakshaks' task force by holding a joint meeting with all school principals of their district. This would serve as a forum or logistical problems.

In addition, a quarterly joint meeting of heads of each district task force and the planning group would be conducted to ensure smooth functioning and feedback to existing issues to ensure a swift and prompt resolution.
Effectiveness evaluation: Baseline and yearly clinical examination of a randomly chosen sample from a group of randomly picked 3 Delhi government schools as mentioned above.

\section{On-line survey}

Quantitative data would be gathered through a short questionnaire among students of participating schools to provide a feedback for the program and also provide baseline and yearly status of oral health related knowledge, attitude and oral hygiene practice. Feedback forms would also be circulated during educational session among both parents and children.

\section{Focus groups}

Separate focus group discussions with students, teachers and parents would be an appropriate method to gauge the different perspectives towards the programme. ${ }^{38}$

Draw and write

This method allows children of all age groups to give their views without the limitation of language and words. ${ }^{39}$

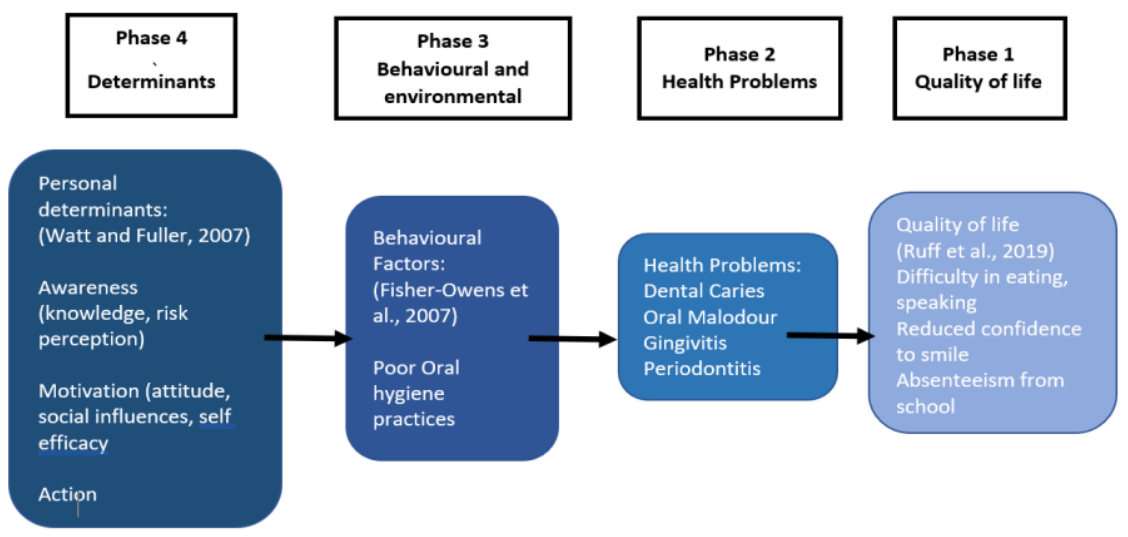

Figure 1: Logic model of problem for oral health program.

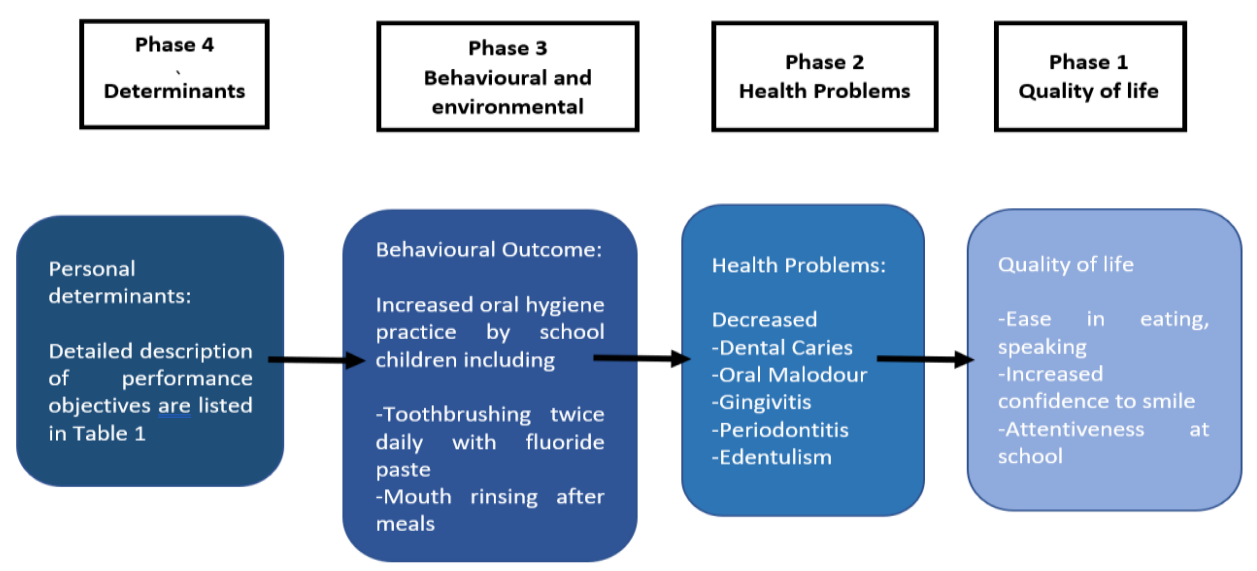

Figure 2: Logic model of change for oral health program. 
Table 1: Program outcomes and objectives matrix.

\begin{tabular}{|c|c|c|}
\hline $\begin{array}{l}\text { Stage of } \\
\text { integrated } \\
\text { change } \\
\text { model }\end{array}$ & $\begin{array}{l}\text { Target behaviour: } \\
\text { - Toothbrushing twice daily with fluoride toothpaste by } \\
\text { school children } \\
\text { - Mouth rinsing after meals by all school children }\end{array}$ & Objectives \\
\hline Awareness & $\begin{array}{l}\text { Knowledge: } \\
\text {-Toothbrushing appropriately twice daily and mouth rinsing } \\
\text { after meals daily improves oral health and reduces risk of } \\
\text { developing dental caries and gingivitis. } \\
\text { Risk perception: } \\
\text { - Poor oral hygiene does not necessarily lead to poor oral } \\
\text { health and oral diseases. }\end{array}$ & $\begin{array}{l}\text {-To increase knowledge among school children that } \\
\text { toothbrushing and mouth rinsing results in } \\
\text { improvement of oral hygiene and maintains good oral } \\
\text { health. } \\
\text {-To increase awareness among school children that } \\
\text { every individual is susceptible to Oral diseases. } \\
\text { Increased risk with poor oral hygiene. }\end{array}$ \\
\hline Motivation & $\begin{array}{l}\text { Attitude: } \\
\text {-Toothbrushing and mouth rinsing are a waste of time, have } \\
\text { no major advantages } \\
\text { - Useless to communicate the oral health goals to others } \\
\text { - Too lazy to do toothbrushing and mouth rinsing - Good } \\
\text { oral hygiene may not lead to good oral health } \\
\text { Social support: } \\
\text {-Parents perception and perceived importance of oral health } \\
\text {-No school focuses on children's oral health } \\
\text { Self-efficacy: } \\
\text {-Belief that individual will not be able to brush teeth in } \\
\text { correct manner. } \\
\text { - Belief that individual will not be able to find time to brush } \\
\text { teeth twice daily }\end{array}$ & $\begin{array}{l}\text {-To convince children that toothbrushing and mouth } \\
\text { rinsing have more benefits. } \\
\text {-To convince children that toothbrushing and mouth } \\
\text { rinsing will be easy to achieve after communicating } \\
\text { the oral hygiene goal to others including parents and } \\
\text { peers } \\
\text {-To convince the school for introduction of an oral } \\
\text { health policy. } \\
\text { - To convince parents about learning health benefits } \\
\text { of oral hygiene } \\
\text {-Enhance confidence among school children in being } \\
\text { able to learn the correct way of tooth brushing } \\
\text {-Enhance confidence among school children in } \\
\text { managing competing demands on time/ resources }\end{array}$ \\
\hline Action & $\begin{array}{l}\text { Action planning: } \\
\text { - Poor skill for using tooth brush appropriately } \\
\text { Preparatory Planning: } \\
\text { - Lack of provision of fluoride tooth paste and tooth brush at } \\
\text { home for children to use. }\end{array}$ & $\begin{array}{l}\text { - Enhance the skill of using tooth brush appropriately } \\
\text { by children } \\
\text { - Ensure provision of fluoride tooth paste and tooth } \\
\text { brush at home for children to use. }\end{array}$ \\
\hline
\end{tabular}

Table 2: Matrix for program outcomes, objectives, BCTs and practical applications.

\begin{tabular}{|c|c|c|c|c|}
\hline $\begin{array}{l}\text { Stage of } \\
\text { integrated } \\
\text { change } \\
\text { model }\end{array}$ & $\begin{array}{l}\text { Target behaviour: } \\
\text { - Toothbrushing twice daily } \\
\text { with fluoride toothpaste by } \\
\text { school children } \\
\text { - Mouth rinsing after meals } \\
\text { by all school children }\end{array}$ & Objectives & $\begin{array}{l}\text { Behaviour } \\
\text { change strategy }\end{array}$ & $\begin{array}{l}\text { Communication method/ } \\
\text { practical application }\end{array}$ \\
\hline Awareness & $\begin{array}{l}\text { Knowledge: } \\
\text {-Toothbrushing appropriately } \\
\text { twice daily and mouth rinsing } \\
\text { after meals daily improves } \\
\text { oral health and reduces risk } \\
\text { of developing dental caries } \\
\text { and gingivitis. } \\
\text { Risk Perception: } \\
\text { - Poor oral hygiene does not } \\
\text { necessarily lead to poor oral } \\
\text { health and oral diseases. }\end{array}$ & $\begin{array}{l}\text {-To increase knowledge } \\
\text { among school children that } \\
\text { toothbrushing and mouth } \\
\text { rinsing results in } \\
\text { improvement of oral } \\
\text { hygiene and maintains good } \\
\text { oral health. } \\
\text {-To increase awareness } \\
\text { among school children that } \\
\text { every individual is } \\
\text { susceptible to Oral diseases. } \\
\text { Increased risk with poor oral } \\
\text { hygiene. }\end{array}$ & $\begin{array}{l}\text {-Using Imagery } \\
\text { figure } \\
\text {-Chunking } \\
\text { (Theories of } \\
\text { Information } \\
\text { processing; Gobet } \\
\text { et al., 2001) } \\
\text {-Verbal persuasion } \\
\text {-Advance } \\
\text { organizers }\end{array}$ & $\begin{array}{l}\text {-Video with familiar animation } \\
\text { - Toothbrushing demonstration } \\
\text { by teacher } \\
\text { - Increasing depth and detail of } \\
\text { oral health education video } \\
\text { material for each age group- } \\
\text { junior, middle and senior } \\
\text { school. } \\
\text {-Video with familiar animation } \\
\text { figure explaining risks } \\
\text { associated with poor oral } \\
\text { hygiene. } \\
\text {-Flyers with each video giving }\end{array}$ \\
\hline Motivation & $\begin{array}{l}\text { Attitude: } \\
\text {-Toothbrushing and mouth } \\
\text { rinsing are a waste of time, } \\
\text { have no major advantages } \\
\text { - Useless to communicate the } \\
\text { oral health goals to others } \\
\text { - Too lazy to do } \\
\text { toothbrushing and mouth } \\
\text { rinsing - Good oral hygiene } \\
\text { may not lead to good oral } \\
\text { health }\end{array}$ & $\begin{array}{l}\text {-To convince children that } \\
\text { toothbrushing and mouth } \\
\text { rinsing have more benefits. } \\
\text {-To convince children that } \\
\text { toothbrushing and mouth } \\
\text { rinsing will be easy to } \\
\text { achieve after } \\
\text { communicating the oral } \\
\text { hygiene goal to others } \\
\text { including parents and peers } \\
\text {-To convince the school for } \\
\text { introduction of an oral } \\
\text { health policy. } \\
\text { - To convince parents about } \\
\text { learning health benefits of } \\
\text { oral hygiene } \\
\text {-Enhance confidence among } \\
\text { school children in being }\end{array}$ & $\begin{array}{l}\text {-Fear arousal; } \\
\text { arguments } \\
\text {-Consciousness } \\
\text { raising } \\
\text {-Personalize risk } \\
\text {-Mobilizing social } \\
\text { support } \\
\text {-Verbal persuasion } \\
\text {-Guided Practice } \\
\text {-Self Monitoring } \\
\text { of behaviour }\end{array}$ & $\begin{array}{l}\text {-Animated video depicting the } \\
\text { process of dental caries and its } \\
\text { sequelae } \\
\text {-Introduction of toothbrushing } \\
\text { record in the students' school } \\
\text { diary with weekly checks. } \\
\text {-Class based video adaptation } \\
\text { to ensure tailored material } \\
\text { depending on the age group. } \\
\text { - Introduction of parents to } \\
\text { program to ensure support to } \\
\text { toothbrushing at home } \\
\text {-Toothbrushing demonstration } \\
\text { by teacher } \\
\text {-Video and face to face } \\
\text { educational session for parents } \\
\text { to enhance social support for }\end{array}$ \\
\hline
\end{tabular}




\begin{tabular}{|c|c|c|c|c|}
\hline $\begin{array}{l}\text { Stage of } \\
\text { integrated } \\
\text { change } \\
\text { model }\end{array}$ & $\begin{array}{l}\text { Target behaviour: } \\
\text { - Toothbrushing twice daily } \\
\text { with fluoride toothpaste by } \\
\text { school children } \\
\text { - Mouth rinsing after meals } \\
\text { by all school children }\end{array}$ & Objectives & $\begin{array}{l}\text { Behaviour } \\
\text { change strategy }\end{array}$ & $\begin{array}{l}\text { Communication method/ } \\
\text { practical application }\end{array}$ \\
\hline & $\begin{array}{l}\text { Self-efficacy: } \\
\text {-Belief that individual will } \\
\text { not be able to brush teeth in } \\
\text { correct manner. } \\
\text { - Belief that individual will } \\
\text { not be able to find time to } \\
\text { brush teeth twice daily }\end{array}$ & $\begin{array}{l}\text { able to learn the correct way } \\
\text { of tooth brushing } \\
\text {-Enhance confidence among } \\
\text { school children in } \\
\text { managingcompeting } \\
\text { demands on time/resources }\end{array}$ & & $\begin{array}{l}\text { tooth brushing and mouth } \\
\text { rinsing at home. } \\
\text {-Video with familiar animation } \\
\text { figure } \\
\text { - Toothbrushing record in the } \\
\text { students' school diary }\end{array}$ \\
\hline Action & $\begin{array}{l}\text { Action Planning: } \\
\text { - Poor skill for using tooth } \\
\text { brush appropriately } \\
\text { Preparatory Planning: } \\
\text { - Lack of provision of } \\
\text { fluoride tooth paste and tooth } \\
\text { brush at home for children to } \\
\text { use. }\end{array}$ & $\begin{array}{l}\text { - Enhance the skill of using } \\
\text { tooth brush appropriately by } \\
\text { children } \\
\text { - Ensure provision of } \\
\text { fluoride tooth paste and } \\
\text { tooth brush at home for } \\
\text { children to use. }\end{array}$ & $\begin{array}{l}\text {-Guided Practice } \\
\text {-Verbal persuasion } \\
\text {-Reinforcement } \\
\text {-Mobilizing social } \\
\text { support } \\
\text {-Public } \\
\text { commitment }\end{array}$ & $\begin{array}{l}\text {-Toothbrushing demonstration } \\
\text { by teacher } \\
\text {-Take home flyers and making } \\
\text { videos available for children } \\
\text { and parents to revise. } \\
\text { - Animated video explaining } \\
\text { toothbrushing in a step by step } \\
\text { manner } \\
\text {-Involving parents to make a } \\
\text { public commitment plus ensure } \\
\text { provision of tooth brush and } \\
\text { fluoride toothpaste }\end{array}$ \\
\hline
\end{tabular}

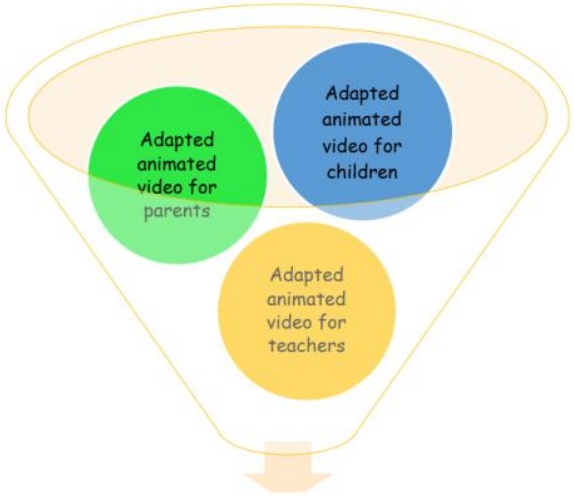

Figure 3: Adaptations of animated videos for INSTABrush program.

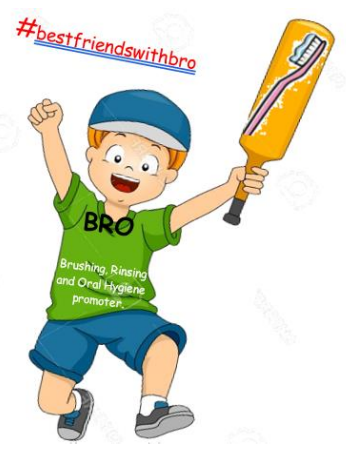

Figure 4: Animated character- BRO.

\section{CONCLUSION}

The present paper attempts to highlight the growing public health concern around oral disease which is especially prevalent among children in the Indian subcontinent. It also proposes the I-change framework as a potential base for developing school based programs aimed at improving poor oral health associated behaviour among children. Following a step by step guide through each phase of the framework, the author has put forth a practically feasible model for school based oral health program.

\section{ACKNOWLEDGEMENTS}

Authors would like to thank Professor Keilong Cheung for being a constant source of support and ideas.

Funding: No funding sources

Conflict of interest: None declared

Ethical approval: Not required

\section{REFERENCES}

1. Watt RG. Strategies and approaches in oral disease prevention and health promotion. Bulletin of the World Health Organization. 2005;83:711-8.

2. Hescot P. The new definition of oral health and relationship between oral health and quality of life. Chin J Dent Res. 2017;20(4):189-92.

3. NACOH. Healthy mouths healthy lives: Australia's National Oral Health Plan 2004-2013. Adelaide, National Advisory Committee on Oral Health, Australian Health Ministers' Advisory Council. 2004.

4. Watt R, Fuller S. Practical aspects of oral health promotion, Community Oral Health, (C Pine, R Harris Eds.), United Kingdom, Quintessence. 2007;357-75.

5. Dhar V, Jain A, Dyke TE, Kohli A. Prevalence of dental caries and treatment needs in the school-going children of rural areas in Udaipur district. J Indian Soc Pedodont Prev Dentistr. 2007;25(3):119.

6. Saravanan S, Anuradha KP, Bhaskar DJ. Prevalence of dental caries and treatment needs among school going children of Pondicherry, India. J Indian Soc Pedodont Prev Dentistr. 2003;21(1):1-12.

7. Vellappally S, Jacob V, Smejkalová J, Shriharsha P, Kumar V, Fiala Z. Tobacco habits and oral health status in selected Indian population. Central Eur J Public Health. 2008;16(2). 
8. Dasgupta U, Mallik S, Naskar S, Choudhury K, Paria B, Bhattacharya SK. Dental problems and its epidemiological factors-a study on adolescent and adult patients attending dental OPD of a tertiary care hospital in Kolkata, India. J Dent Med Sci. 2013;5:1-7.

9. Arora G, Mackay DF, Conway DI, Pell JP. Ethnic differences in oral health and use of dental services: cross-sectional study using the 2009 Adult Dental Health Survey. BMC Oral Health. 2016;17(1):1.

10. Mittal M, Chaudhary P, Chopra R, Khattar V. Oral health status of 5 years and 12 years old school going children in rural Gurgaon, India: an epidemiological study. J Indian Soc Pedod Prev Dent. 2014;32(1):3-8.

11. Mathur MR, Tsakos G, Millett C, Arora M, Watt R. Socioeconomic inequalities in dental caries and their determinants in adolescents in New Delhi, India. BMJ Open. 2014;4(12):e006391.

12. Leal SC, Bronkhorst EM, Fan M, Frencken JE. Untreated cavitated dentine lesions: impact on children's quality of life. Caries Res. 2012;46(2):102-6.

13. Krisdapong S, Prasertsom P, Rattanarangsima K, Sheiham A. Sociodemographic differences in oral health-related quality of life related to dental caries in thai school children. Community Dent Health. 2013;30(2):112-8.

14. Jin LJ, Lamster IB, Greenspan JS, Pitts NB, Scully C, Warnakulasuriya S. Global burden of oral diseases: emerging concepts, management and interplay with systemic health. Oral Dis. 2016;22(7):609-19.

15. Kwan SY, Petersen PE, Pine CM, Borutta A. Healthpromoting schools: an opportunity for oral health promotion. Bull World Health Org. 2005;83:677-85.

16. Ruff RR, Senthi S, Susser SR, Tsutsui A. Oral health, academic performance, and school absenteeism in children and adolescents: A systematic review and metaanalysis. J Am Dent Assoc. 2019;150(2):111-21.

17. Jürgensen N, Petersen PE. Promoting oral health of children through schools-Results from a WHO global survey 2012. Comm Dent Health. 2013;30(4):204-18.

18. Retnaningsih D, Arinti R. Habit of tooth brushing with the dental caries incidence. Int $J$ Res Med Sci. 2018;6(8):2606.

19. Kumar S, Panwar J, Vyas A, Sharma J, Goutham B, Duraiswamy P, Kulkarni S. Tooth cleaning frequency in relation to socio-demographic variables and personal hygiene measures among school children of Udaipur district, India. Int J Dent Hygiene. 2011;9(1):3-8.

20. Gupta T, Sequeira P, Acharya S. Oral health knowledge, attitude and practices of a 15-year-old adolescent population in Southern India and their social determinants. Oral Health Prev Dentistr. 2012;10(4).

21. Watt RG, Marinho VC. Does oral health promotion improve oral hygiene and gingival health? Periodontology. 2005;37:35-47.

22. Eldredge LKB, Markham CM, Ruiter RA, Fernández ME, Kok G, Parcel GS. Planning health promotion programs: an intervention mapping approach. John Wiley \& Sons. 2016.

23. Petersen PE, Bourgeois D, Ogawa H, Estupinan-Day S, Ndiaye C. The global burden of oral diseases and risks to oral health. Bull World Health Org. 2005;83:661-9.

24. Spanemberg JC, Cardoso JA, Slob EMGB, LópezLópez J. Quality of life related to oral health and its impact in adults. J Stomatol Oral Maxillofac Surg. 2019;120(3):234-9.
25. Kakudate N, Morita M, Fukuhara S, Sugai M, Nagayama M, Kawanami M, Chiba I. Application of self-efficacy theory in dental clinical practice. Oral Dis. 2010;16(8):747-52.

26. Albino J, Tiwari T. Preventing childhood caries: a review of recent behavioral research. J Dent Res. 2016;95(1):35-42.

27. Glanz K, Rimer BK, Viswanath K. Theory, research, and practice in health behavior and health education. Jossey-Bass. 2008.

28. Solhi M, Zadeh DS, Seraj B, Zadeh SF. The application of the health belief model in oral health education. Iranian J Public Health. 2010;39(4):114.

29. Fisher-Owens SA, Gansky SA, Platt LJ, Weintraub JA, Soobader MJ, Bramlett MD, Newacheck PW. Influences on children's oral health: a conceptual model. Pediatrics. 2007;120(3):510-20.

30. Bartholomew LK, Parcel GS, Kok G, Gottlieb NH. Intervention mapping: designing theory-and evidencebased health promotion programs. Mountain View, CA: Mayfield. 2001.

31. Burnside G, Pine CM, Curnow M, Nicholson J, Roberts A. Long-term motivational effects of an RCT of supervised toothbrushing, The International Association of Dental Research 86th General Session Oral Health Disparities, Knowledge, Promotion: Toronto. 2008.

32. Curnow M, Pine C, Burnside G, Nicholson J, Roberts A. Caries prevalence six years after the cessation of a RCT, The International Association of Dental Research 86th General Session: Toronto. 2008.

33. Davies GM. 'Department of health, British Association for the study of community Dentistry, Delivering better oral health: an evidence-based toolkit for prevention. London: Deportment of health Dental updates. 2008;35:460-2.

34. Scherr CL, Nam K, Augusto B, Kasting ML, Caldwell M, Lee MC, Meade CD, Pal T, Quinn GP, Vadaparampil ST. A Framework for Pilot Testing Health Risk Video Narratives. Health Commun. 2020;35(7):832-41.

35. Ayo-Yusuf OA, Reddy PS, van den Borne BW. Longitudinal association of adolescents' sense of coherence with tooth-brushing using an integrated behaviour change model. Community Dent Oral Epidemiol. 2009;37(1):68-77.

36. Woodall J, Woodward J, Witty K, McCulloch S. An evaluation of a toothbrushing programme in schools. Health Education. 2014;114(6).

37. World Health Organization. Oral health surveys: basic methods. World Health Organization. 2013. Available at: $\quad$ https://apps.who.int/iris/handle/10665/97035. Accessed on 24 January 2021.

38. Then KL, Rankin JA, Ali E. Focus group research: what is it and how can it be used? Canad J Cardiovasc Nurs. 2014;24(1):16-22.

39. Hartel J. An arts-informed study of information using the draw-and-write technique. J Assoc Information Sci Tech. 2014;65(7):1349-67.

Cite this article as: Mehra R. Change model for a school-based program to promote oral hygiene practices among Indian school children. Int J Community Med Public Health 2021;8:3662-70. 